\title{
Benthic community establishment on different concrete mixtures introduced to a German deep-water port
}

\author{
Lydia R. Becker ${ }^{1,2,3^{*}} \mathbb{D}$, Ingrid Kröncke ${ }^{2,4}$, Andreas Ehrenberg ${ }^{5}$, Volkert Feldrappe ${ }^{5}$ and Kai Bischof ${ }^{3^{*}}$
}

\begin{abstract}
Concrete is a widely used building material in coastal constructions worldwide. However, limited natural resources used in the production process, as well as high $\mathrm{CO}_{2}$-emission due to the calcination process of limestone and the thermal energy demand for Portland cement clinker production, raise the demand for alternative constituents. Alternative mixture types should be environmentally friendly and, at best, mimic natural hard substrates. Here five different concrete mixtures, containing different cements (Portland cement and blast furnace cements) and aggregates (sand, gravel, iron ore and metallurgical slags) were made. Three replicate cubes $(15 \times 15 \times 15 \mathrm{~cm})$ of each type were then deployed in a German deep-water Port, the JadeWeserPort, to study benthic community establishment after one year. Results are compared to a similar experiment conducted in a natural hard ground environment (Helgoland Island, Germany). Results indicate marked differences in settled communities in the Port site compared to natural environments. At the Port site community composition did not differ with the concrete mixtures. Surface orientation of the cubes (front/top/back) revealed significant differences in species abundances and compositions. Cubes hold more neobiota in the Port site than in natural hard ground environments. Implications for the usage of new concrete mixtures are discussed.
\end{abstract}

Keywords: Coastal constructions, Succession, Fouling communities

\section{Introduction}

Coastal infrastructures do not function as surrogate for natural marine habitats. Even though artificial structures act as key anthropogenic drivers of environmental change to coastal habitats worldwide [1], ecological consequences of their introduction to the marine environment, to date, have received relatively little attention [2-8]. However, there is a growing consensus that artificial structures are different to natural rocky shores or biogenic reefs [1, 2, 9-13]. In most instances, coastal

\footnotetext{
*Correspondence: Ikohlmorgen@marum.de; kai.bischof@uni-bremen.de ${ }^{1}$ INTERCOAST Research Training Group, University of Bremen, Leobener Strasse, 28359 Bremen, Germany

${ }^{3}$ Department of Marine Botany, University of Bremen, Leobener Str. NW2, 28359 Bremen, Germany

Full list of author information is available at the end of the article
}

infrastructure is built in areas which otherwise are characterised as soft bottom habitats; here the change in species composition, abundance and diversity through the change of the natural habitat origin becomes particularly clear [14].

While natural habitats slope gently or have heterogeneous topography, artificial constructions frequently provide vertical habitat $[6,15-17]$. This can lead to increased densities of certain species and to an increasing strength of interspecific interactions $[1,18]$. Understanding of how species do or do not use artificial structures is still in its infancy. To date, the characteristics of communities that are likely to establish on or near artificial structures are not predictable [1]. Observation of the community establishment on newly introduced artificial structures 
thus helps to understand the ecological value of a structure itself.

The release of artificial substrata initiates primary succession. Primary succession starts with physiochemical events and occurs on very small spatial scales. Physiochemical events are followed by a biological colonization by bacteria and diatoms [19]. From this point on, succession is regarded as a continuous process with changing trajectories, deflected by both physical and biological processes. A temporary "final stage" of succession, where most of the substrata is covered by macrofauna organisms $>1 \mathrm{~cm}$ and subsequently only small changes occur, is reached after approximately one year of deployment in most cases [19]. Further studies on succession of coastal infrastructure can be found, for instance, in biofouling literature, where processes are extensively discussed [20-23].

Newly raised artificial structures are susceptible to invasion, first of all, because of the new, open space [2427]. Further reasons for invasion can be poor environmental conditions, frequent disturbances, or support of activities linked to the introduction of exotic species (e.g. shipping, aquaculture) [1]. Especially globalization and extended marine traffic within the last century, together with an increase in infrastructure on coasts worldwide, increase the risks of introducing non-indigenous species, so called neobiota [1]. This is especially true for artificial structures in big ports, which are connected to shipping routes worldwide. Neobiota generally appear in greater proportions on artificial structures than in adjacent natural habitats [25] potentially due to a higher tolerance to environmental stressors [28], reduced competitive interactions with extant species and or by lower mortality by predation $[29,30]$.

Closely connected systems of artificial structures for example along the European coastlines, provide additional dispersal routes for neobiota, also causing drastic changes to natural environments close by [2, 25]. For example, Undaria pinnatifida, a brown algae species native to East Asian shores, was introduced into the Mediterranean in 1971 with Pacific oysters. Intentional introduction from there to the French Atlantic coast 12 years later led to a gradual spread to the British Isles and recently to the North Sea [31]. Environmental agencies worldwide are monitoring species causing such changes to the natural marine environment, particularly under the European Water Framework Directive and the Marine Strategy Framework Directive.

European coastlines are covered by $22.000 \mathrm{~km}^{2}$ of concrete or asphalt [32-34]. Due to its availability, durability (50-100 years), formability and low in price, concrete has become one of the most important construction materials worldwide [35]. However, the availability of natural resources, commonly used in aggregates, are limited [3638]. The reduction of Portland cement production and the increase of supplementary cementitious materials, like granulated blast furnace slags, a byproduct of pig iron production, is a desired achievement in the cement industry [39-41]. The use of slags from metal production (e.g. steel, copper) is promising. These offer technical advantages due to their mineral properties, and have been used in road construction and armor stones for decades [42]. For aquatic environments, their usage is controversial because of the potential for uncontrolled leaching of heavy metals out of pure slag stones [43]. The European concrete standards regulations are not standardized on the usage of aggregates, thus the usage depends on assessments in specific projects.

The following study closely relates to the results of a succession experiment on concrete cubes made of different mixtures which contained different cements (Portland cement and blast furnace cements) and aggregates (natural sand, gravel, iron ore and metallurgical slags). The cubes for this study were deployed in an underwater experimental area and test facility within a natural hard ground environment near Helgoland Island in the German Bight [44]. In order to compare succession on natural and artificial structures, we report here on a settlement experiment on concrete cubes made of the same mixtures and deployed in the same time span as in Becker et al. [44], but in a completely different environment; the JadeWeserPort as an example of a recently erected artificial habitat (Wilhelmshaven, Germany). Here, it is most likely that additional marine coastal infrastructure will be built, and further anthropogenic influences are to be expected.

Taking the JadeWeserPort as a representative example of a recently established artificial infrastructure with high anthropogenic impact, this study focuses on the following questions:

(1) Are there differences in the benthic communities settled on different mixture types after one year of deployment in an anthropogenically influenced area?

(2) Are observed patterns different to succession studies in a natural hard ground area (e.g. near Helgoland Island)? How do both areas differ in terms of species composition on the concrete blocks?

(3) Are there implications for the usability of alternative concrete constituents in marine constructions?

\section{Material and methods}

\section{Deployment site and experimental design}

The JadeWeserPort is the most eastern deep-water port from the "Nordrange", it is the most important 
continental European Ports of the North Sea [45] and is tide-independent up to $18 \mathrm{~m}$ water depth (Fig. 1a). Port construction started in 2008; in April 2012 its trial operation started and it has been running official business since September 2012 [45]. It holds 130 hectare of Container Terminal out of 340 hectare total area. It has a turnover capacity of 2.7 million TEU/Year [46]. In 2019, transfer of 29.29 Mio $t$ were documented, which is $+7 \%$ compared to 2018 [47]. The neobiota report of the German coast line 2014 [48] reports a total of 116 taxa for the JadeWeserPort, of which 17 were neobiota to the German North Sea coastline.

The deployment site of the concrete cubes was in a separated part of the harbor, the service port. In total, 15 concrete cubes $(15 \times 15 \times 15 \mathrm{~cm})$ made of five different concrete mixtures, were fixed on five steel-PVC-frames $(1 \mathrm{~m} \times 0.25 \times 0.30 \mathrm{~m})$. Each frame was rigged with three cubes. The different mixtures were randomly placed in the frames, with the exception that none of the different mixtures were present in the same frame twice (Fig. 1b). The frames were deployed from swimming pontoons in April 9th, 2017 and submerged $\sim 1.5 \mathrm{~m}$ beneath the surface and fixed by ropes.

The swimming pontoons had previously been reported as the species richest habitat of the harbor [48]. Here, a total of 63 Taxa was found, 14 of them were neobiota [48]. It was further reported that eight out of the 14 neobiota were only found at the JadeWeserPort pontoons.

\section{Concrete mixtures}

Concretes used in the experiments fulfill the requirements for exposure class "XS2" (marine structures being permanently under water) defined in the non-standardised EU concrete standard EN 206. The cement content was $320 \mathrm{~kg} / \mathrm{m}^{3}$ and the water/cement ratio was 0.5 in all cases.

Mixtures differed in the used cement types and aggregates. In mixture 1-mixture 3, a Portland cement CEM I $42.5 \mathrm{R}$ and two blast furnace cements CEM III/A $42.5 \mathrm{~N}$ and CEM III/B $42.5 \mathrm{~N}$ were used as binders. Natural sand $\left(2.64 \mathrm{~kg} / \mathrm{dm}^{3}\right)$, gravel $\left(2.64 \mathrm{~kg} / \mathrm{dm}^{3}\right)$ and iron ore "MagnaDense" $\left(4.90 \mathrm{~kg} / \mathrm{dm}^{3}\right)$ were used in slightly different concentrations (Table 1). In mixture 4 and 5 , blast furnace cement (CEM III/B 42.5 N) was combined with two metallurgical slags (a copper slag "Iron Silicate" and an electric arc furnace slag "EOS" with $3.80 \mathrm{~kg} / \mathrm{m}^{3}$ and $3.60 \mathrm{~kg} / \mathrm{m}^{3}$ ) as aggregates (Table 1). All cements used fulfilled the requirements of the European cement standard EN 197-1. Since blast furnace cements provide a very dense structure with a low capillary porosity, they are commonly used for durable concrete structures in the marine environment $[33,49,50]$.

In accordance with EN 12390-2, the "Institut für Baustoffforschung FEhS Duisburg" produced three cubes $\left(15 \times 15 \times 15 \mathrm{~cm}^{3}\right)$ of each of the five different mixtures (M1-M5) in February 2017. The cubes were stored 1 day in their mold, 6 days under water, and then under constant climate conditions at $20{ }^{\circ} \mathrm{C}$ and $65 \%$ relative moisture. At the end of March 2017, they were transported to Wilhelmshaven.

The concretes' compressive strengths were measured in accordance with EN 12390-3 after 2 and 28 days of casting. The results are shown in Table 2. M5, the mixture with the electric arc furnace slag aggregate, had a significantly higher strength after 28 days, due to the very high grain strength of EOS.

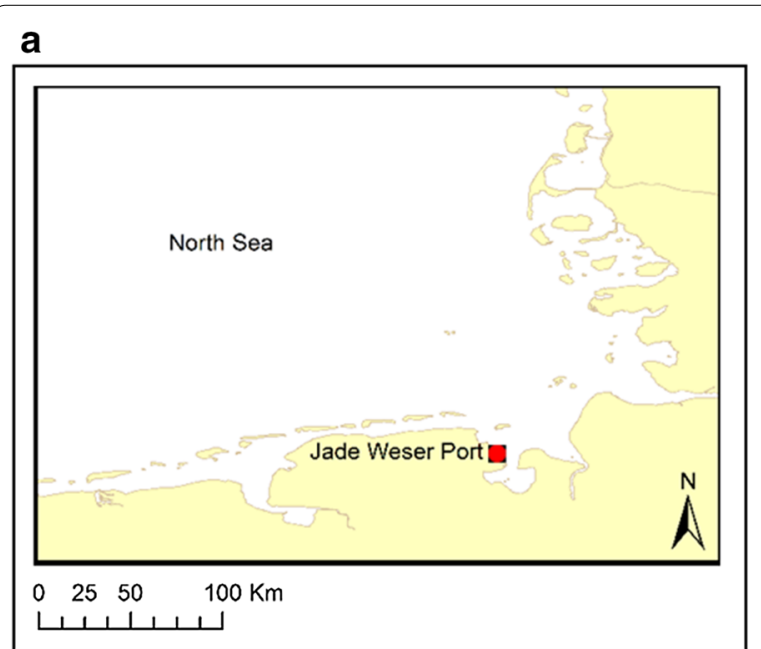

b

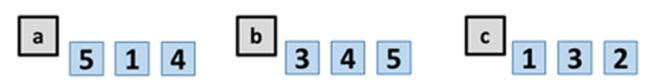

Fig. 1 Deployment site and experimental set up - a Location of the JadeWeserPort; tiles were deployed in the service port. $\mathbf{b}$ Order of frames $\mathbf{a}-\mathbf{e}$; numbers 1-5 show the location of the different concrete mixtures 


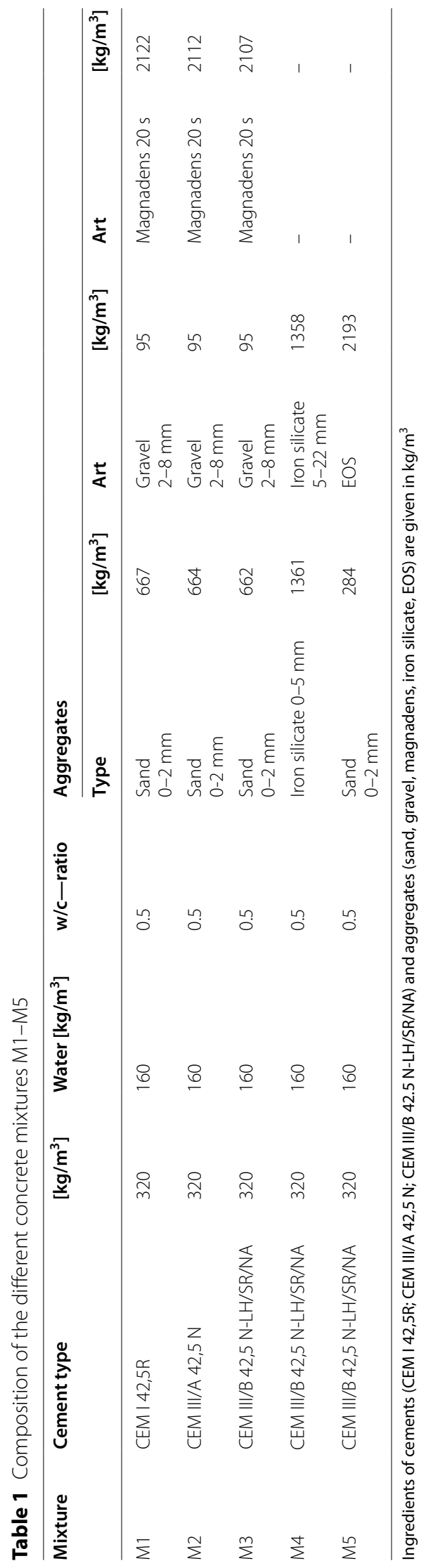




\section{Sampling procedure and analysis}

The concrete cubes were retrieved on April 16th, 2018, after a one year deployment (April 9th, 2017-April 16th, 2018). Until evaluation, they were stored in darkness in saltwater at $\sim 10{ }^{\circ} \mathrm{C}$. The cubes were examined in the lab from April 16th 2018 to April 19th 2018. Three cube sides, the top, front and backside, were evaluated. The front side is defined as the cube side, which points in the direction of the open water, the back side is defined as the cube side, which points to the pontoon (Fig. 1b). All macrofauna and algal species present on the top, front and backside of the concrete cubes $(15 \times 15 \mathrm{~cm})$ were recorded. Additionally, each side was photographically documented. Species were determined to the lowest possible taxonomic level and for smaller species, abundance and coverage were recorded using a smaller grid (1 $\mathrm{cm}^{2}=0.44 \%$ coverage of the total area).

For comparison of the different sides and mixture types, only coverage data was used in the statistical analysis. Mobile macrofauna species or species with less than five individuals per cube side were excluded from the analysis. One community was summed up as "mat", including species of juvenile Phaeophyceae and cyanobacterial communities, as well as diatoms species. They formed a visible crust on the cubes.

All neobiota were identified according to neobiota catalogues [51, 52]. Categories (K1-K3) were assigned accordingly: K1 Neobiota with a known strong impact on the environment. K2 Neobiota with a known strong impact on the environment, but this impact is still not present on regional coasts. K3 Neobiota with to date unknown consequences to the environment [51].

\section{Data processing and statistical analysis}

Statistical analysis were performed using the statistical PRIMER package, v6 [53] and PERMANOVA + add on PRIMER v6 [54]. Univariate 1-way PERMANOVA tests, based on square root transformed coverage data, as well as multivariate analysis of the transformed data via PERMANOVA pair-wise tests, based on Bray-Curtis similarity, were performed. P-values yield the exact test of the null hypothesis. This means, the probability of rejecting the null hypothesis is exactly equal to the chosen significant level of 0.05 . The chance of false positive findings

Table 2 Compressive strength $f_{c, \text { cube }}$ of the concrete mixtures M1-M5 in N/mm ${ }^{2}$ after 2 and 28 days under constant climate conditions at $20^{\circ} \mathrm{C}$ and $65 \%$ relative moisture

\begin{tabular}{llllll}
\hline & M1 & M2 & M3 & M4 & M5 \\
\hline 2 days & 43.5 & 40.1 & 41.1 & 41.7 & 43.5 \\
28 days & 59.1 & 58.4 & 56.4 & 60.4 & 72.0 \\
\hline
\end{tabular}

(type I error) is 5\% [54]. MDS plots were used to show trends in multivariate data. DIVERSE tool and similarity percentage routine (SIMPER) analysis were used to determine differences in species communities. Mean coverage and standard deviations were calculated in $\mathrm{R}$ v.3.3.2 [55]. Coverage values over $100 \%$ were found due to the horizontal and partially overlapping distribution of species.

\section{Results}

\section{Benthic flora and fauna}

After one year of deployment, 32 macrofauna and algal taxa were identified in total on all concrete cubes. Five of these taxa belong to the group of neobiota $(K 1=1$ species and two species classified as K2 and K3). With five different taxa, Mollusca represented the most diverse group, followed by Arthropoda (4), Phaeophyceae (4), and Rhodophyta (4). Other taxonomic groups were represented two or less taxa per group (Table 3). The following statistical analysis include \%-coverage of nine taxa and one taxa named "mat" (which includes 3 juvenile species of Phaeophycaea and diatoms).

\section{Differences between the observed mixtures and sides}

Permanova revealed no differences in community composition for the different mixtures (M1-M5), but confirmed highly significant differences $(\mathrm{P}=0.0001)$ between macrofauna and algal communities of the top side $(\mathrm{T})$, the front side $(\mathrm{F})$, and the back side (B) of the cubes (Table 4).

Differences between the observed sides of the concrete cubes were also shown by the MDS plot of square root transformed coverage data (Fig. 2). Permanova pair-wise test confirmed significant differences between all sides (T-F P $=0.0001$, T-B P $=0.0001, \mathrm{~F}-\mathrm{B} \mathrm{P}=0.0001$ ).

\section{Side effect}

Taxa numbers are similar between the Top and Front sides (T: $4.31 \pm 0.91 ; \mathrm{F}: 4.62 \pm 0.62$ ), only the Back differed with one taxa less (B: $3.31 \pm 0.46$ ). The Top sides of the cubes revealed lower mean coverages $(51.23 \pm 19.04 \%)$ compared to the Front $(118.54 \pm 21.69 \%)$ and Back $(97.38 \pm 29.77 \%)$ sides (Table 5). Shannon-Wiener index $H^{\prime}$ was highest for the Top sides $(1.07 \pm 0.15)$. For the Front sides, a Shannon-Wiener index of $0.97 \pm 0.19$, and for the Back sides, a Shannon-Wiener index $\mathrm{H}^{\prime}$ of $0.88 \pm 0.13$ was calculated. Eveness J' was $0.75 \pm 0.15$ for the Top sides, $0.63 \pm 0.1$ for the Front sides, and $0.74 \pm 0.11$ for the Back sides of the cubes (Table 5). SIMPER analysis indicated differences in species communities between the sides. While the Top communities were dominated by red algae Polysiphonia nigrescens (46.33\%), followed 
Table 3 List of macrofauna and algal taxa found on the concrete cubes

\begin{tabular}{|c|c|c|c|c|}
\hline Phylum/class & Order & Family & Species & Neobiota \\
\hline \multirow[t]{4}{*}{ Arthropoda } & Amphipoda & Gammaridae & Gammarus spec & \\
\hline & Decapoda & Cancridae & Cancer pagurus & \\
\hline & Sessila & Austrobalanidae & Austrominius modestus & K2 \\
\hline & & & Balanus crenatus & \\
\hline \multirow[t]{2}{*}{ Bryozoa } & Cheilostomatida & Bugulidae & Crisularia purpurotincta & \\
\hline & & Electridae & Electra pilosa & \\
\hline \multirow[t]{2}{*}{ Chlorophyta } & Ulvales & Ulvaceae & Ulva spp & \\
\hline & Ulvales & Ulotrichaceae & Acrosiphonia arcta & \\
\hline Chordata & Stolidobranchia & Styelidae & Botryllus schlosseri & K3 \\
\hline \multirow[t]{2}{*}{ Cnidaria } & Actiniaria & Actiniidae & Urticina juv & \\
\hline & & & Urticina felina & \\
\hline Echinodermata & Forcipulatida & Asteriidae & Asterias rubens & \\
\hline \multirow[t]{2}{*}{ Hydrozoa } & Anthoathecata & Tubulariidae & Tubularia indivisa & \\
\hline & & & "Club polyp" & \\
\hline \multirow[t]{5}{*}{ Mollusca } & Littorinimorpha & Calyptraeidae & Crepidula fornicata & K2 \\
\hline & Mytilida & Mytilidae & Mytilus edulis & \\
\hline & Nudibranchia & Onchidorididae & Onchidoris bilamellata + Gelege & \\
\hline & Ostreida & Ostreidae & Crassostrea gigas & K1 \\
\hline & Trochida & Trochidae & Gibbula spec & \\
\hline Phaeophyceae & Ectocarpales & Acinetosporaceae & Hincksia hincksiae & \\
\hline \multirow[t]{3}{*}{ (mat) } & & & Pilayella spp & \\
\hline & & & Pilayella littoralis & \\
\hline & & Ectocarpaceae & Ectocarpus siliculosus & \\
\hline \multirow[t]{3}{*}{ Polychaeta } & Phyllodocida & Polynoidae & Harmothoe glabra & \\
\hline & & & Harmothoe antilopes & \\
\hline & Terebellida & Terebellidae & "Polychaete mud tube"s & \\
\hline Porifera & Suberitida & Halichondriidae & Halichondria (Halichondria) panicea & \\
\hline \multirow[t]{4}{*}{ Rhodophyta } & Bonnemaisoniales & Bonnemaisoniaceae & Bonnemaisonia hamifera & K3 \\
\hline & Ceramiales & Rhodomelaceae & Ceramium rubrum & \\
\hline & & Rhodomelaceae & Polysiphonia nigrescens & \\
\hline & Corallinales & Lithothamniaceae & Phymatolithon spp & \\
\hline
\end{tabular}

Species \%-coverage included in the JadeWeserPort analysis are shown in bold. Species of the Phylum Phaeophyceae and diatoms built a mat cover on the cubes and were included as such in the statistical analysis. Risk categories are given (K1-K3) [51]

Table 4 Results of Permanova on square root transformed coverage data showing differences in macrofauna and algal communities between different sides (Top vs Front vs. Back)

\begin{tabular}{lclllll}
\hline Source & df & SS & MS & Pseudo-F & P(perm) & Unique perms \\
\hline Sides & 2 & 23,183 & 11,592 & 27.763 & $0.0001^{* *}$ & 9940 \\
Mixture & 4 & 2094 & 523.5 & 1.2539 & 0.275 & 9929 \\
Sides $\times$ mixture & 8 & 1603.3 & 200.41 & 0.48002 & 0.955 & 9923 \\
Res & 24 & 10,020 & 417.52 & & & \\
Total & 38 & 38,455 & & & & \\
\hline
\end{tabular}

No differences were present for mixtures (M1-M5). Analysis implies no interaction between side effect and mixtures effect. Meaning that the effect within side and mixtures is the same within the tested groups

$d f$ degrees of freedom, SS sum of squares, MS mean sum of squares, Pseudo $F$ pseudo-F ratio. Significance levels $P$ (perm) are based on 9999 permutations (significance levels: *significant $(p \leq 0.05)$, **highly significant $(p \leq 0.005))$. Unique perms indicate how many unique values of the test statistic were obtained under permutation 


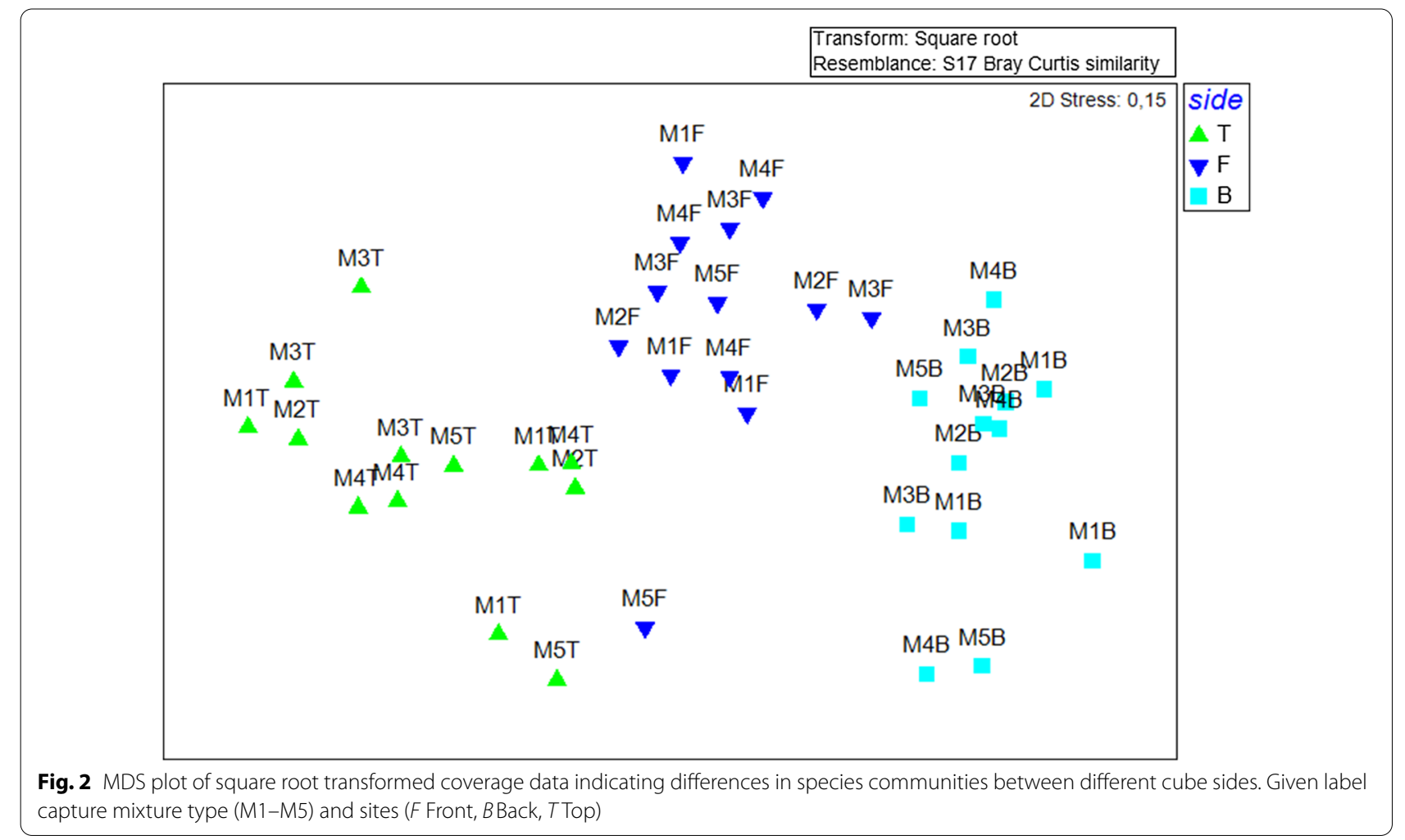

Table 5 Results of DIVERSE and SIMPER analysis for the top, front and back sides of the cubes

\begin{tabular}{|c|c|c|c|}
\hline Site & Top & Front & Back \\
\hline Mean taxa per side & $4.31(0.99)$ & $4.62(0.68)$ & $3.31(0.5)$ \\
\hline Mean coverage [\%] & $51.23(20.63)$ & $118.54(23.5)$ & $97.38(32.25)$ \\
\hline $\begin{array}{l}\text { Shannon-Wiener } \\
\text { index } H^{\prime}\end{array}$ & $1.07(0.29)$ & $0.97(0.21)$ & $0.88(0.14)$ \\
\hline Eveness J' & $0.75(0.16)$ & $0.63(0.1)$ & $0.74(0.12)$ \\
\hline $\begin{array}{l}\text { Species communi- } \\
\text { ties resulting from } \\
\text { SIMPER analysis }\end{array}$ & $\begin{array}{l}\text { Polysiphonia } \\
\text { nigrescens } \\
(46.33) \\
\text { mat (26.20) } \\
\text { Balanus crena- } \\
\text { tus (14.23) } \\
\text { "Polychaete } \\
\text { mud tubes" } \\
\text { (10.17) }\end{array}$ & $\begin{array}{l}\text { mat (56.39) } \\
\text { Polysiphonia } \\
\text { nigrescens } \\
\text { (22.93) } \\
\text { Balanus crena- } \\
\text { tus (10.52) } \\
\text { Crisularia } \\
\text { purpurotincta } \\
\text { (7.28) }\end{array}$ & $\begin{array}{l}\text { mat (48.47) } \\
\text { Balanus } \\
\text { crenatus } \\
\text { (29.94) } \\
\text { Crisularia pur- } \\
\text { purotincta } \\
\text { (21.07) }\end{array}$ \\
\hline
\end{tabular}

Shown are mean taxa, mean coverage, Shannon-Wiener index $\mathrm{H}^{\prime}$ and Eveness J'. Standard deviations are shown in brackets. SIMPER analysis shows characterizing macrofauna and algal species, and to which percentage they contribution to the communities (in brackets) on the different sites

by mat species (26.20\%), Balanus crenatus (14.23\%) and "Polychaete mud tubes" (10.17\%), the Front sides were dominated by the mat species (56.39\%), Polysiphonia nigrescens (22.93\%), Balanus crenatus (10.52\%), and Crisularia purpurotincta (7.28). The Back sides, like the Front sides, were also dominated by mat species $(48.47 \%)$ but then followed by Balanus crenatus (29.94\%) and Crisularia purpurotincta (21.07\%) (Table 5).

\section{Neobiota in the JadeWeserPort}

Five out of the total of 32 taxa found on the concrete cubes were recorded as neobiota, belonging to all of the three different risk categories: K1-Crassostera gigas; K2-Austrominius modestus, Crepidula fornicata; K3-Botryllus schlosseri, Bonnemaisonia hamifera (Table 3). Abundances of Crassostera gigas were low being found on 6 out of 45 cube sides, with less than five individuals per side. Abundances of Austrominius modestus were also low being found on 1 out of 45 cube sides, with less than five individuals per side. In 26 out of 45 cube sides, individuals of Crepidula fornicata were present at densities of 1-4 individuals per side, however on three sides, 10-25 individuals were present. Abundances of Botryllus schlosseri were low with three small colonies found on 5 sides. Bonnemaisnia hamifera was found on 13 out of 45 cube sides, with coverage mostly less than $5 \%$ per side but one side was found with $30 \%$.

\section{Discussion}

The findings within this study contribute to a better understanding of the process of settlement of benthic communities on artificial constructions, and further 
highlight that these structures cannot act as surrogates to natural grounds. In the context of a continuously increasing activity of constructing new marine coastal infrastructure [32-34], the investigation of new concrete mixtures is necessary with regards to resource efficiency, sustainability and economical aspects. There is more than one concrete type which can be used in coastal constructions, to safeguard natural resources. Testing different mixtures in the natural environment, is not only important for the evaluation of ecological impacts, but also concerning durability and static requirements.

In the JadeWeserPort, concrete mixture type made no differences to settled communities after one year. However, surface orientation of the cubes (Front/Top/Back) revealed significant differences in species abundances and community compositions. In a similar experimental setting, however in a less anthropogencially shaped environment, Becker et al. [44] observed different results. Here, the same concrete mixtures were exposed within the same period of time to the natural subtidal hard ground conditions of Helgoland Island. Becker et al. [44] also observed significant differences of settlement communities depending on the surface orientation of the cubes, but also significant differences in settled communities between mixture types. They suggests that concrete mixture type is negligible in anthropogenically influenced sites but more study sites are needed to confirm this. Impacts of artificial material in inshore coastal hard bottom communities might not necessarily be the same as for Helgoland, which, due to its relatively isolated location in the German Bight is offshore character [56].

Constructions of marine artificial infrastructure have been influencing natural environmental conditions for decades, for instance by changes in water flow, contamination loads, noise etc., and have impacted species richness and diversity which cannot be readily reversed [1, 57]. In nearshore environments, fragmentation of rocky shore habitats by replacing natural rock with artificial substrata, leads to a loss of habitat and changes the characteristics of the remaining assemblages [58]. The subdivision into numerous smaller habitat patches results in an overall reduction in species richness [59]. Species present in anthropogenically influenced sites are characterized by a generally broad range of tolerance [1] Changes, for instance in concrete ingredients, will probably be of minor importance to those species. Natural hard grounds, in contrast, hold higher numbers of propagules, species that are more specialized and react more sensitive to small range environmental changes $[1,13$, 57]. This might result in more drastic and visible changes in the settling community structures depending on mixture types.

\section{Species composition and abundances in anthropogenically} influenced and natural sites

Artificial constructions like ports, are known to differ from natural hard grounds in terms of community composition and species densities [57, 60]. Studies on artificial constructions found reduced species richness compared to the neighbouring natural communities [1, 61-63].

For the cubes deployed in the JadeWeserPort, a total of 32 taxa was found. This is low, compared to a total of 51 taxa found on the cubes of the natural hard ground study site in Helgoland by Becker et al. [44]. Comparing results of taxa numbers given by other studies conducted in the JadeWeserPort and Helgoland, the trend towards lower species diversity in the port site is also observed. For the JadeWeserPort a total of 116 taxa [48] is reported where at the natural site Helgoland, up to 402 taxa can be found [64]. Other studies show similar results. For instance, a recent comparison of concrete jetties versus natural rocky shores of the Mediterranean revealed a total of 150 algal and faunal taxa, 77 were recorded on jetties while 140 were recorded on natural rocky shores [65].

The floating pontoons in the JadeWeserPort were reported as the habitat of the harbor richest in species [48]. With a total of 63 taxa, they held more than half of all taxa found in the port site. Studies on floating and fixed artificial structures suggest, that the motion of floating structures, like pontoons, influence species composition and abundances [66, 67]. In temperate regions, differences between floating and fixed structures were mainly due to increased abundances of species [25, 6669]. For tropical environments, changes in community composition were observed as well, for instance, more filter feeding organisms were found on floating structures, compared to fixed habitats $[66,67]$. This might be explained by higher water flow and turbulence through these structures. This trend is also reflected by community composition found for the pontoons in the JadeWeserPort by Rhode et al. [48].

Regarding species composition, only eight red and brown algal species were found in the JadeWeserPort. The red alga Polysiphonia nigrescens dominated over all others covering most of the front sites of the cubes after the second month of deployment. Polysiphonia nigrescens was missing on the back side of the cubes, and here, barnacles dominated the surface. The back side of the cubes is shaded by the pontoons and since algae species need light for growth, it is reasonable that they preferred the open water side. However, taxa numbers of algae found on the concrete cubes in the port are considerably lower, compared to the natural study site, where cubes were covered by 23 algal taxa after one year of deployment. The proximity to natural rocky coastlines or reefs 
influence community characteristics on artificial constructions $[57,60]$. The JadeWeserPort is surrounded by a mud flat environment. Thus, the pool of reproductive spores potentially reaching artificial structures to settle is low compared to the natural hard ground environments [13].

Water transparency in anthropogenic port sites is often considerably low, especially when a mud flat environment surrounds them. This is critical, as light availability is a main factor limiting the growth of algal species. Regular dredging activities in the port and in the channels close by, in combination with the regular tide flow, can increase the percentage of small mud particles in the water column [70-73]. In the JadeWeserPort, water transparency is already low in 0.5 to $1 \mathrm{~m}$ [48], as measured by Secchi depth. For the North Sea areas, water transparency increases with distance to the shore lines [74]. For the natural site Helgoland, mean water transparency lies already around 4-5 m Secchi depth [75, 76], a value which can hardly be measured in the proximity of anthropogenic construction sites.

Apart from a higher diversity of algae, more Bryozoan species were found at the natural study site as well, compared to the JadeWeserPort [44]. In addition to water transparency, water contamination levels influence species diversity. The southern parts of the North Sea are under the influence of the rivers Elbe, Weser, Ems, Rhein, Schelde and Thames. Hence, contamination levels with respect to brackish water inflow and industrial loads through these rivers are higher compared to the isolated position of Helgoland Island [56]. Studies from the Red Sea coast show that bryozoan species react sensitively to environmental pollution, mainly heavy metal contamination in soils. Diversity of Bryozoan species was higher in unpolluted areas than in anthropogenically influenced coastal sites [77]. Although we did not assess heavy metal load at the study site, it is likely that a higher contamination level in port sites may influence species diversity.

For the JadeWeserPort, the barnacle Balanus crenatus were among the characteristic species, especially for the cubes' back sides. Barnacles are typical settling organisms on artificial structures worldwide [20-23, 78]. Within artificial constructions, barnacles prefer vertically orientated structures, but this can vary depending on sediment loads [79]. Other species typical for artificial constructions can be tube building polychaetes, like Spriobranchus triqueter or Spirobis spirobis for temperate regions, both missing from the JadeWeserPort study site $[65,79]$.

\section{Neobiota}

The experiments in the JadeWeserPort affirm a high invasion risk of artificial structures, as argued, for instance, in Glasby et al. [80]. All five neobiota found in this study were also included in the total of 14 neobiota found on the pontoon site in the JadeWeserPort by Rhode et al. [48]. However, abundances of neobiota were still low, compared to dominating native species. A fast succession of native competitors, for instance Polysiphonia nigrescens might have prevent the settlement by neobiota.

Since 1954, the barnacle Austominius modestus has been one of the main fouling species in German coastal waters [51]. After a series of mild winters and warm summers, exponential population growth was observed in several North Sea regions [51, 81]. This might become problematic with further increasing temperature due to climate change. A model on two competing barnacle species with different reproduction times (as would the case for Austrominius modestus and Balanus crenatus) revealed a positive impact of warming waters for invasive species due to a reduced time period between the reproductive peaks of the species [82]. However, native species can be supported and positively influenced by the precise timing of the introduction of new substrates [82]. In the present study, the native barnacle Balanus crenatus still dominated on the cubes of the JadeWeserPort. The slipper snail Crepidula fornicata, also introduced from England where it spread to most European ports, has been established as part of the German marine fauna since 1934. Its abundance is still strongly reduced by cold winters [51]. On the cubes in the JadeWeserPort, the pacific oyster Crassostera gigas was also found being introduced to the North Sea waters in the middle of the twentieth century where in the Wadden Sea, it replaced native mussel beds of Mytilus edulis. Hitherto, Crassostera gigas can be found along almost all European coastlines [51]. At the natural study site of Helgoland Becker et al. [44] observed two neobiota (Botryllus schlosseri and Bonnemaisonia hamifera) but they do not seem to have a negative impact on the natural environment [51].

There are several reasons given as to why artificial structures are particularly vulnerable to invasion. Those reasons entail a generally lower diversity of native species, reduced competitive interaction and predation risk, but also changes in environmental conditions, like a reduced water flow in more sheltered conditions [1]. For breakwaters along the coasts of Italy a spread of introduced green macroalgae has been found [12, 24]. Algae benefit from the wave-sheltered environments on the shoreward side of the breakwaters [12, 24]. Dafforn et al. [28] argue that filter-feeding invaders, which are often transported on ship hulls, could take advantage of being adapted to high shear stress by colonizing open space on moving substrata, for instance floating docks. Regarding reduced competitive interactions and predation risk, as postulated by the biotic resistance theory [29] and enemy 
release hypotheses [30], it also needs to be taken into account that artificial structures always initiate primary succession when they are built or released to marine environments. It is difficult to predict, if neobiota will manage to replace native competitors in the long term. However, with ongoing climate change and global trade and transport it is likely that neobiota will succeed over native species $[83,84]$.

In conclusion, a general recommendation can be given with respect to the use of new concrete mixtures in marine constructions. As long as there is no significant difference in succession patterns and establishment of benthic communities between the new concrete mixtures and those which are commonly provided, and that leakage of environmental pollutants can be excluded, the new mixtures should be used for new constructions. This way, at least a more environmentally friendly production would be guaranteed. However, it is important to balance between costs and benefits of new concrete mixtures and building solutions may differ from case to case.

\begin{abstract}
Acknowledgements
We thank the JadeWeserPort for support of our work. We thank Maik Wilsenack, Ralf Kuhlmann, Hermann Neumann, and Michael Becker for help with logistics. Thanks to Vanessa Köhler, Karin Springer, Gesine Lange and students for help with identifying species and doing photographic documentations. Thanks to Prof. Dr. Conrad Pilditch for linguistic revisions.

\section{Authors' contributions}

L. R. Becker: conceptualization, methodology, validation, formal analysis, investigation, writing —original draft, writing — review and editing, project administration, visualization. K. Bischof: conceptualization, writing —review and editing, supervision. I. Kröncke: validation, writing —review and editing, supervision. A. Ehrenberg: conceptualization, methodology, resources, writing - review and editing. V. Feldrappe: methodology, resources, writingreview and editing. All authors read and approved the final manuscript.
\end{abstract}

\section{Funding}

Open Access funding enabled and organized by Projekt DEAL. This research was funded by the DFG ('German Research Foundation') within the INTERCOAST ('Integrated Coastal Zone and Shelf-Sea Research') graduate program, a joint collaboration between the Senckenberg Institute in Wilhelmshaven (Germany), the University of Bremen (Germany), and the University of Waikato (New Zealand) and by the FEhS Institute Duisburg.

\section{Availability of data and materials}

The datasets used and/or analysed during the current study are available from the corresponding author on reasonable request.

\section{Declarations}

Ethics approval and consent to participate Not applicable.

\section{Consent for publication}

Not applicable.

\section{Competing interests}

The authors declare that they have no competing interests.

\section{Author details}

${ }^{1}$ INTERCOAST Research Training Group, University of Bremen, Leobener Strasse, 28359 Bremen, Germany. ${ }^{2}$ Department for Marine Research,
Senckenberg Am Meer, Südstrand 40, 26382 Wilhelmshaven, Germany. ${ }^{3}$ Department of Marine Botany, University of Bremen, Leobener Str. NW2, 28359 Bremen, Germany. ${ }^{4}$ Institute for Chemistry and Biology of the Marine Environment, University of Oldenburg, Schleusenstr. 1, 26382 Wilhelmshaven, Germany. ${ }^{5}$ FehS-Institut Für Baustoff-Forschung E.V., Bliersheimer Straße 62, 47229 Duisburg, Germany.

Received: 12 June 2020 Accepted: 8 June 2021

Published online: 19 June 2021

\section{References}

1. Bulleri F, Chapman MG. The introduction of coastal infrastructure as a driver of change in marine environments. J Appl Ecol. 2010;47:26-35.

2. Glasby TM, Connell SD. Urban structures as marine habitats. Ambio. 1999;28:595-8.

3. Southward AJ, Orton JH. The effects of wave-action on the distribution and numbers of the commoner plants and animals living on the Plymouth breakwater. J Mar Biol Assoc UK. 1954;33:1-19.

4. Connell SD. Urban structures as marine habitats: an experimental comparison of the composition and abundance of subtidal epibiota among pilings, pontoons and rocky reefs. Mar Environ Res. 2001;52:115-25.

5. Hawkins SJ, Allen JR, Ross PM, Genner MJ. Marine and coastal ecosystems. In: Perrow MR, Davy AJ, editors. Handbook of ecological restoration in practice. Cambridge: Cambridge University Press; 2002. p. 121-48.

6. Chapman MG. Paucity of mobile species on constructed seawalls: effects of urbanization on biodiversity. Mar Ecol Prog Ser. 2003;264:21-9.

7. Bulleri F. Is it time for urban ecology to include the marine realm? Trends Ecol Evol. 2006;21:656-8.

8. Airoldi L, Abbiati M, Beck MW, Hawkins SJ, Jonsson PR, Martin D, et al. An ecological perspective on the deployment and design of low-crested and other hard coastal defence structures. Coast Eng. 2005;52:1073-87.

9. Bulleri F. The introduction of artificial structures on marine soft- and hard-bottoms: ecological implications of epibiota. Environ Conserv. 2005;32:101-2.

10. Firth LB, Thompson RC, Bohn K, Abbiati M, Airoldi L, Bouma TJ, et al. Between a rock and a hard place: environmental and engineering considerations when designing coastal defence structures. Coast Eng. 2014;87:122-35.

11. Firth LB, Knights AM, Bridger D, Evans AJ, Mieszkowska N, Moore PJ, et al. Ocean sprawl: challenges and opportunities for biodiversity management in a changing world. Oceanogr Mar Biol Annu Rev. 2017:2016(54):193-269.

12. Vaselli S, Bulleri F, Benedetti-Cecchi L. Hard coastal-defence structures as habitats for native and exotic rocky-bottom species. Mar Environ Res. 2008;66:395-403. https://doi.org/10.1016/j.marenvres.2008.06.002.

13. Bulleri F. Role of recruitment in causing differences between intertidal assemblages on seawalls and rocky shores. Mar Ecol Prog Ser. 2005:287:53-64.

14. Bacchiocchi F, Airoldi L. Distribution and dynamics of epibiota on hard structures for coastal protection. Estuar Coast Shelf Sci. 2003;56:1157-66.

15. Perkol-Finkel S, Benayahu Y. Community structure of stony and soft corals on vertical unplanned artificial reefs in Eilat (Red Sea): comparison to natural reefs. Coral Reefs. 2004;23:195-205.

16. Moschella PS, Abbiati M, Åberg P, Airoldi L, Anderson JM, Bacchiocchi F, et al. Low-crested coastal defence structures as artificial habitats for marine life: Using ecological criteria in design. Coast Eng. 2005;52:1053-71.

17. Lam NWY, Huang R, Chan BKK. Variations in intertidal assemblages and zonation patterns between vertical artificial seawalls and natural rocky shores: a case study from Victoria Harbour. Hong Kong Zool Stud. 2009:48:184-95.

18. Moreira J, Chapman MG, Underwood AJ. Seawalls do not sustain viable populations of limpets. Mar Ecol Prog Ser. 2006;322 Smallwood 2001:179-88

19. Noël LM-LJ, Griffin JN, Moschella PS, Jenkins SR, Thompson RT, Hawkins SJ. Changes in diversity and ecosystem functioning during succession. In: Wahl M, editor. Marine hard bottom communities, ecological studies 206. Berlin Heidelberg: Springer-Verlag; 2009. p. 213-23. 
20. Haderlie EC. A brief overview of the effects of marofouling. In: Costlow JD, Tipper RC, editors. Marine biodeteroration: an interdisciplinary study. Annapolis: Naval Institute Press; 1984. p. 163-6.

21. Hole W. Marine fouling and its prevention. Maryland: Annapolis; 1952.

22. Howell D, Behrends B. A review of surface roughness in antifouling coatings illustrating the importance of cutoff length. Biofouling 2006;22:401-10.

23. Yan T, Yan WX. Fouling of offshore structures in China-a review. Biofouling. 2003;19:133-8

24. Bulleri F, Airoldi L. Artificial marine structures facilitate the spread of a non-indigenous green alga, Codium fragile ssp. tomentosoides, in the north Adriatic Sea. J Appl Ecol. 2005:42:1063-72.

25. Glasby TM, Connell SD, Holloway MG, Hewitt CL. Nonindigenous biota on artificial structures: could habitat creation facilitate biological invasions? Mar Biol. 2007;151:887-95

26. Neves CS, Rocha RM, Pitombo FB, Roper JJ. Use of artificial substrata by introduced and cryptogenic marine species in Paranaguá Bay, southern Brazil. Biofouling. 2007;23:319-30.

27. Tyrrell MC, Byers JE. Do artificial substrates favor nonindigenous fouling species over native species? J Exp Mar Bio Ecol. 2007;342:54-60.

28. Dafforn KA, Johnston EL, Glasby TM. Shallow moving structures promote marine invader dominance. Biofouling. 2009;25:277-87.

29. Elton CS. The ecology of invasion by animals and plants. London: Methuen; 1958.

30. Keane RM, Crawley MJ. Exotic plant invasions and the enemy release hypothesis. Trends Ecol Evol. 2002;17:164-70.

31. Schiller J, Lackschewitz D, Buschbaum C, Reise K, Pang S, Bischof K. Heading northward to Scandinavia: Undaria pinnatifida in the northern Wadden Sea. Bot Mar. 2018;61:365-71.

32. Airoldi L, Beck M. Loss, status and trends for coastal marine habitats of Europe. Oceanograph Marine Biol. 2007:45:345-405.

33. Bijen J. Blast furnace slag cement for durable marine structures. Stichting Betonprisma (Association of the Netherlands Cement Industry), s'Hertogenbosch, Netherlands; 1996.

34. Kosmatka SH, Kerkhoff B, Panarese WC. Design and control of concrete mixtures. EB001, 14th edition, Portland Cement Association, Skokie, Illinois, USA, 2002

35. Jensen BL, Glavind M. Consider the environment - why and how. Sustainable concrete production - Proceedings of the International Conference held at the University of Dundee, UK, on 9-11 September; 2002. p. 14

36. Assi L, Carter K, Deaver E (Eddie), Anay R, Ziehl P. Sustainable concrete: building a greener future. J Clean Prod. 2018;198:1641-51. https://doi. org/10.1016/j.jclepro.2018.07.123.

37. Crow MJ. The concrete conundrum. Chem World. 2008;March:62-66.

38. United Nations Envionment Programme. Sand and sustainability: finding new solutions for environmental governance of global sand resources. Geneva: Switzerland; 2019.

39. Ehrenberg A. Granulated blast furnace slag - from laboratory into practice. 14th Int Congr Chem Cem. 2015. http://www.iccc2015beijing.org/ dct/page/1

40. Schneider M, Romer M, Tschudin M, Bolio H. Sustainable cement production-present and future. Cem Concr Res. 2011;41:642-50. https:// doi.org/10.1016/j.cemconres.2011.03.019.

41. bbs. The demand for primary and secondary raw materials in the mineral and building materials industry in Germany up to 2030. 2016; p. 1-5.

42. EC. Information day on utilization of blast furnace and steelmaking slags. Liège Belgium: Commission of the European Communities; 1988

43. BfG. Umweltaspekte des Einsatzes von industriell hergestellten Wasserbausteinen in Bundeswasserstraßen. Koblenz; 2008.

44. Becker LR, Ehrenberg A, Feldrappe $V$, Kröncke I, Bischof $K$. The role of artificial material for benthic communities_establishing different concrete materials as hard bottom environments. Mar Environ Res. 2020. https:// doi.org/10.1016/j.marenvres.2020.105081.

45. JWP. Basis-Information JadeWeserPort. Wilhelmshaven; 2020.

46. JWP. Imagebroschüre JadeWeserPort-Das GVZ JadeWeserPort. Wilhelmshaven; 2020.

47. Jahrespressekonferenz Niedersächsiche Seehäfen. Niedersachsens Seehäfen erzielen mit 53,5 Mio. Tonnen das beste Ergebnis der letzten 10 Jahre. 2020. https://www.jadeweserport.de/presse-media/news/4764/. Accessed 19 Mar 2020.
48. Rhode S, Schupp P, Markert A, Wehrmann A. Neobiota - Basislinie in niedersächsischen Küstengewässern. 2015. Bericht erstellt im Auftrag des NLWKN und NLPV.

49. Eckhardt A, Kronsbein W. Beton und Zement in Seewasser. 1950.

50. Schröder HT, Hallauer O, ScholzW. Beständigkeit verschiedener Betonarten in Meerwasser und in sulfathhaltigem Wasser. 1975.

51. Lackschewitz D, Reise K, Buschbaum C, Karez R. Neobiota in deutschen Küstengewässern. 2014.

52. BLANO. Neobiota-Plattform. by Fach AG Neobiota. 2020. https://www neobiota-plattform.de/english/neobiota-platform/. Accessed 19 Mar 2020.

53. Clarke RK, Gorley RN. PRIMER V6: User Manual - Tutorial. Prim Plymouth Mar Lab. 2006; p. 1-190.

54. Anderson MJ, Gorley RN, Clarke KR. PERMANOVA+ for PRIMER guide to software and statistical methods. Prim Plymouth, UK. 2008; p. 1-217.

55. R Development Core Team. R: a language and environment for statistical computing. 2016. www.r-project.org.

56. de Kluijver MJ. Sublittoral hard substrate communities off Helgoland. Helgoländer Meeresuntersuchungen. 1991;45:317-44.

57. Airoldi L, Connell SD, Beck MW. The loss of natural habitats and the addition of artificial substrata. In: Wahl M, editor. Marine hard bottom communities, ecological studies 206. Berlin Heidelberg: Springer-Verlag; 2009. p. 269-80.

58. Fahrig L. Effects of habitat fragmentation on biodiversity. Annu Rev Ecol Evol Syst. 2003;34:487-515.

59. Debinski DM, Holt RD. A survey and overview of habitat fragmentation experiments. Conserv Biol. 2000;14:342-55.

60. Clynick BG, Blockley D, Chapman MG. Anthropogenic changes in patterns of diversity on hard substrata: an overview. In: Wahl M, editor. Marine hard bottom communities, ecological studies 206. Berlin Heidelberg: SpringerVerlag; 2009. p. 247-56.

61. Airoldi L, Balata D, Beck MW. The Gray Zone: relationships between habitat loss and marine diversity and their applications in conservation. J Exp Mar Bio Ecol. 2008;366:8-15. https://doi.org/10.1016/j.jembe.2008.07.034.

62. Sella I, Perkol FS. Blue is the new green-ecological enhancement of concrete based coastal and marine infrastructure. Ecol Eng. 2015;84:260-72. https://doi.org/10.1016/j.ecoleng.2015.09.016.

63. Gacia E, Satta MP, Martin D. Low crested coastal defence structures on the Catalan coast of the Mediterranean Sea: how they compare with natural rocky shores. Sci Mar. 2007;71:259-67.

64. Boos K, Buchholz C, Buchholz F, Gutow L. Bericht über die Zusammensetzung des Helgoländer Makrozoobenthos im Vergleich historischer und aktueller Quellen - Klassifizierungsvorschlag nach der WRRL und Empfehlungen zum Monitoring. 2004

65. Bonnici L, Borg JA, Evans J, Lanfranco S, Schembri PJ. Of rocks and hard places: comparing biotic assemblages on concrete jetties versus natural rock along a microtidal mediterranean shore. J Coast Res. 2018;345:1136-48.

66. Perkol-Finkel S, Zilman G, Sella I, Miloh T, Benayahu Y. Floating and fixed artificial habitats: effects of substratum motion on benthic communities in a coral reef environment. Mar Ecol Prog Ser. 2006;317 July:9-20.

67. Perkol-Finkel S, Zilman G, Sella I, Miloh T, Benayahu Y. Floating and fixed artificial habitats: spatial and temporal patterns of benthic communities in a coral reef environment. Estuar Coast Shelf Sci. 2008;77:491-500.

68. Glasby TM. Development of sessile marine assemblages on fixed versus moving substrata. Mar Ecol Prog Ser. 2001;215 May:37-47.

69. Holloway MG, Connell SD. Why do floating structures create novel habitats for subtidal epibiota? Mar Ecol Prog Ser. 2002;235 September:43-52.

70. Gutperlet R. Habitat dynamics in response to constructional impacts (JadeWeserPort): a biological approach. Dissertation, Bremen; 2016.

71. Gutperlet R, Capperucci RM, Bartholomä A, Kröncke I. Relationships between spatial patterns of macrofauna communities, sediments and hydroacoustic backscatter data in a highly heterogeneous and anthropogenic altered environment. J Sea Res. 2017;121:33-46. https://doi.org/10. 1016/j.seares.2017.01.005

72. Schückel U, Beck M, Kröncke I. Macrofauna communities of tidal channels in Jade Bay (German Wadden Sea): spatial patterns, relationships with environmental characteristics, and comparative aspects. Mar Biodivers. 2015:45:841-55.

73. Singer A, Schückel U, Beck M, Bleich O, Brumsack HJ, Freund $\mathrm{H}$, et al. Small-scale benthos distribution modelling in a North Sea tidal basin in 
response to climatic and environmental changes (1970s-2009). Mar Ecol Prog Ser. 2016;551:13-30.

74. Dupont N, Aksnes DL. Centennial changes in water clarity of the baltic sea and the north sea. Estuar Coast Shelf Sci. 2013;131:282-9. https://doi. org/10.1016/j.ecss.2013.08.010.

75. Bartsch I, Tittley I. The rocky intertidal biotopes of Helgoland: present and past. Helgol Mar Res. 2004;58:289-302.

76. Aarup T. Transparency of the North Sea and Baltic Sea-a Secchi depth data mining study. Oceanologia. 2002:44:323-37.

77. El-Sorogy A, Abdel-Wahab M, Ziko A, Shehata W. Impact of some trace metals on bryozoan occurrences, Red Sea coast, Egypt. Indian J Geo-Mar Sci. 2016;45:86-99.

78. Lin H, Wang J, Liu W, Liu K, Zhang S, He X, et al. Fouling community characteristics in subtropical coastal waters of the southwestern East China Sea. Acta Oceanol Sin. 2017;36:70-8.

79. Siddik AA, Al-Sofyani AA, Ba-Akdah MA, Satheesh S. Invertebrate recruitment on artificial substrates in the Red Sea: role of substrate type and orientation. J Mar Biol Assoc UK. 2019;99:741-50.

80. Glasby TM, Connell SD, Holloway MG, Hewitt CL. Nonindigenous biota on artificial structures: could habitat creation facilitate biological invasions? Mar Biol. 2007;151:887-95. https://doi.org/10.1007/s00227-006-0552-5.
81. Witte S, Buschbaum C, van Beusekom JEE, Reise K. Does climatic warming explain why an introduced barnacle finally takes over after a lag of more than 50 years? Biol Invasions. 2010;12:3579-89.

82. Gallagher MC, Arnold M, Kadaub E, Culloty S, O'Riordan RM, McAllen R, et al. Competing barnacle species with a time dependent reproduction rate. Theor Popul Biol. 2020;131:12-24. https://doi.org/10.1016/j.tpb.2019. 11.001 .

83. Hellmann JJ, Byers JE, Bierwagen BG, Dukes JS. Five potential consequences of climate change for invasive species. Conserv Biol. 2008;22:534-43.

84. Buckeridge JS. Opportunism and the resilience of barnacles (Cirripedia: Thoracica) to environmental change. Integr Zool. 2012;7:137-46.

\section{Publisher's Note}

Springer Nature remains neutral with regard to jurisdictional claims in published maps and institutional affiliations.
Ready to submit your research? Choose BMC and benefit from:

- fast, convenient online submission

- thorough peer review by experienced researchers in your field

- rapid publication on acceptance

- support for research data, including large and complex data types

- gold Open Access which fosters wider collaboration and increased citations

- maximum visibility for your research: over $100 \mathrm{M}$ website views per year

At BMC, research is always in progress.

Learn more biomedcentral.com/submissions 